\title{
Impact of Aspergillus fumigatus in allergic airway diseases
}

Neelkamal Chaudhary ${ }^{1}$ and Kieren A Marr ${ }^{1,2^{*}}$

\begin{abstract}
For decades, fungi have been recognized as associated with asthma and other reactive airway diseases. In contrast to type I-mediated allergies caused by pollen, fungi cause a large number of allergic diseases such as allergic bronchopulmonary mycoses, rhinitis, allergic sinusitis and hypersensitivity pneumonitis. Amongst the fungi, Aspergillus fumigatus is the most prevalent cause of severe pulmonary allergic disease, including allergic bronchopulmonary aspergillosis (ABPA), known to be associated with chronic lung injury and deterioration in pulmonary function in people with chronic asthma and cystic fibrosis (CF). The goal of this review is to discuss new understandings of host-pathogen interactions in the genesis of allergic airway diseases caused by A. fumigatus. Host and pathogen related factors that participate in triggering the inflammatory cycle leading to pulmonary exacerbations in ABPA are discussed.
\end{abstract}

\section{Review}

\section{Fungi and Respiratory Allergy}

Fungi are ubiquitous and responsible for causing a broad spectrum of type I-IV hypersensitivity diseases [1]. Recent epidemiologic studies clearly outline the link between fungal sensitization and exacerbations of allergic asthma, leading to increased morbidity and mortality [2-4]. The major respiratory manifestations caused by fungi include allergic bronchopulmonary mycoses (ABPM), severe asthma with fungal sensitization (SAFS), hypersensitivity pneumonitis, fungal sinusitis and allergic rhinitis [1]. In contrast to other allergens (e.g. pollen), fungi also pose a life-threatening risk for invasive pneumonia in immunocompromised patients; further emphasizing their significant impact on human health. It is now understood that the pathogenesis of diseases like asthma and allergy is determined by the interactions between host, genes and environment [5,6]. In this review, we focus on the role of filamentous fungi in respiratory allergic diseases, and discuss how fungi mediate $\mathrm{T}$ helper $(\mathrm{Th}) 2$-mediated allergic diseases as a result of host-pathogen interactions that lead in ineffective clearance of spores, and how predisposing factors like host genetics determine outcomes for respiratory diseases.

\footnotetext{
* Correspondence: kmarr4@jhmi.edu

${ }^{1}$ School of Medicine, Johns Hopkins University, Baltimore, MD, USA

Full list of author information is available at the end of the article
}

\section{Epidemiology and Outcomes}

Amongst the filamentous fungi, Aspergillus species have been strongly linked with exacerbations of asthma and other respiratory allergic diseases $[2,7]$. Over $80 \%$ of Aspergillus-related conditions, such as extrinsic allergic alveolitis, asthma, allergic sinusitis, chronic eosinophilic pneumonia, hypersensitivity pneumonitis, SAFS, and allergic bronchopulmonary aspergillosis (ABPA) are most frequently caused by A. fumigatus [8]. ABPA is the most complex allergic manifestation caused by $A$. fumigatus, and was first reported in the United Kingdom by Hinson et al. in 1952 [9]. Other fungi such as Cryptococcus neoformans and Scedosporium apiospermum are also associated with similar clinical manifestations broadly referred to as ABPM.

Improved diagnostic methods and awareness have led to recent reports of higher prevalence of ABPA in patients suffering from chronic asthma (1-40\%) and acute severe asthma ( 38\%) [10-12]. The prevalence of A. fumigatus hypersensitivity is even higher in patients with acute severe asthma ( 51\%) [12]. A. fumigatus-sensitized asthmatic patients have been reported to have poorer lung function $[13,14]$. ABPA is also prevalent in up to $7-15 \%$ of cystic fibrosis (CF) patients [15-17]. ABPA leads to poorly controlled asthma with pulmonary exacerbations and detrimental consequences; dependence on oral-corticosteroids increases the risk for secondary infections [18]. In rare cases, ABPA disease
C Biomed Central

() 2011 Chaudhary and Marr; licensee BioMed Central Ltd. This is an Open Access article distributed under the terms of the Creative Commons Attribution License (http://creativecommons.org/licenses/by/2.0), which permits unrestricted use, distribution, and reproduction in any medium, provided the original work is properly cited. 
has also been reported to complicate other lung diseases including idiopathic bronchiectasis, chronic obstructive pulmonary disease (COPD) and chronic granulomatous disease [19-21]. Moreover, ABPA has also been reported in patients with pulmonary aspergilloma and chronic necrotizing pulmonary aspergillosis (reviewed in [16]). Diagnostic parameters of ABPA include asthma, roentgenographic fleeting pulmonary opacities, central bronchiectasis, type I and type III hypersensitivity to $A$. fumigatus antigens (discussed in more depth below), and increased peripheral blood eosinophilia [22]. ABPA includes several stages of exacerbations (acute and recurrent) and remissions, central bronchiectasis with pulmonary fibrosis and a possible respiratory failure [22]. However, not all ABPA patients at different stages develop these diagnostic criteria, and some of these features overlap with those of $A$. fumigatus hypersensitivity and asthmatic patients. Uniformity of diagnostic parameters is still needed for improving outcomes in ABPA patients.

\section{Pathogenesis of Fungi \& Airway Clearance}

The most common predisposing factor associated with ABPA pathogenesis is defective clearance of conidia in airways. Airway epithelium, as the first line of defense, extrudes inhaled fungal spores through mucociliary action. Fungal spores evading epithelial mucociliary clearance reach alveoli, and are dealt with by resident phagocytes; neutrophils, as effector cells, efficiently kill germinated hyphal forms through non-oxidative or oxidative-mediated responses. Airway myeloid cells also recognize fungi through pattern recognition receptors (PRRs) such as toll like receptors (TLRs) and Dectin-1, and stimulate the secretion of proinflammatory cytokines/chemokines $[8,23]$. A breached innate immune defense by fungal spores is required for their germination and establishment of fungal-mediated allergies as dormant conidia are immunologically inert [24]. It is thought that ineffective clearance of spores results largely from structural abnormalities in the airway epithelium, as observed in patients with allergic asthma or other causes of chronic lung disease, allowing for germination of spores into vegetative cells (hyphae) [4,25-29].

Fungal hyphae secrete proteases and toxins that damage the airway epithelium, leading to the loss of tight junctions. Epithelium damage leads to increased exposure of A. fumigatus antigens to pulmonary dendritic cells (DCs), which prime naïve Th-cells to Th2 that secrete cytokines such as IL-4, IL-5 and IL-13 leading to IgE isotype switching of B-cells, increased secretion of A. fumigatus-specific IgG, IgE and total IgE antibodies, and pulmonary eosinophilic influx. More than 20 allergens/antigens of $A$. fumigatus have been described to date (http://www.allergen.org). Moreover, several chemokines such as Monocyte Chemotactic protein (MCP-1), Regulated on Activation and Normal T-cell expressed (RANTES), IL-8 and macrophage inflammatory protein-1 $\alpha$ (MIP- $1 \alpha)$ secreted by phagocytic and non-phagocytic cells, perpetuate inflammatory pathology of ABPA [17].

\section{Immunopathogenesis of ABPA in CF patients: Newer Understandings}

CF is caused by mutations in cystic fibrosis transmembrane conductance regulator (CFTR), present on the apical membranes of epithelial cells. Over 1,500 mutations in CFTR are known, and the most common is the deletion of phenylalanine at position $508(\Delta \mathrm{F} 508)$, which causes CFTR protein misfolding and retention in the endoplasmic reticulum (ER) [30]. Filamentous fungi are commonly isolated from sputum of CF patients and $A$. fumigatus is the most prevalent fungal species [31,32]. A. fumigatus-mediated chronic asthma or ABPA in CF patients significantly deteriorates lung function leading to poorer outcomes [27,32-37]. Diagnosis of ABPA in $\mathrm{CF}$ patients further poses a significant challenge as diagnostic criteria such as pulmonary infiltrates, bronchiectasis and obstructive lung disease are common features in CF patients with or without ABPA.

People with ABPA are known to have higher frequencies of CFTR mutations than the healthy population, suggesting that CFTR mutations possibly impact the clearance of A. fumigatus spores [38]. Using the bronchial epithelial cell lines and primary murine tracheal cells, we observed that CFTR mutations/deficiency impact binding and uptake of $A$. fumigatus conidia with differential secretion of inflammatory mediators by $\mathrm{CF}$ cells [39]. Studies have reported improved clinical outcomes for ABPA patients treated with azoles [40,41]. Moreover, anti-fungal therapy also led to the better lung function in A. fumigatus-sensitized CF patients [42]. These studies indicate that $A$. fumigatus actively participate in triggering Th2-type responses that perpetuates in the setting of CFTR mutations [40-42].

Several studies have linked CF genotype to cytokine dysregulation and have shown that immune responses are biased towards Th2 type with increased secretion of proinflammatory cytokines by $\mathrm{CF}$ epithelial cells $[17,43,44]$. These studies indicate that CFTR mutations lead to cytokine milieu which can shift the balance of $A$. fumigatus-specific CD4+ T-cell responses towards Th2. It is also possible that in the setting of $\mathrm{CF}$, there is an increased frequency of $A$. fumigatus-specific CD4+ Th2 cells. Studies by Allard et al. showed that T-cells from naïve CFTR-deficient mice produce higher levels of Th2-cytokines [45]. This study also demonstrated that mice with CFTR-deficiency or mutations develop profound Th2-mediated response to hyphal antigens of $A$. 
fumigatus [45]. That CFTR mutations regulate Th1/Th2 balance was further evident by Muller et al. studies which demonstrated that intra-tracheal delivery of recombinant truncated CFTR reduces levels of Th2cytokines and IgE antibody in CFTR-deficient mouse model of ABPA [46].

The mechanisms of Th2 bias have not been precisely defined. Besides epithelial cells, CFTR is also expressed by other immune cells such as lymphocytes, and alveolar macrophages. Di et al. demonstrated that CFTR-deficient alveolar macrophages fail to undergo lysosomal acidification, potentially leading to an environment conducive for the growth of pathogenic microorganisms [45]. Deficiency of CFTR on CD4+ T-lymphocytes leads to aberrant calcium fluxes causing an increased nuclear translocation of Nuclear factor of activated T-cells (NFAT) possibly driving Th2-biased responses [47]. Most recently, Kreindler et al. demonstrated that Th2 reactivity in CF-ABPA patients was dependent on the expression of costimulatory molecule OX40 ligand (OX40L) on DCs which decreased on in vitro addition of vitamin D3 [48]. Thus, CF patients exhibit multifactorial defects in both pulmonary innate and adaptive immunity to pathogens; modulation of host immunity due to the chronic airway infection with $A$. fumigatus possibly leads to the establishment of ABPA.

\section{Fungi- Factors and Host Immune Response Fungal Proteases}

Fungal proteases are potent allergens, triggering pulmonary allergic responses [7,49-51]. Aspergillus species are known to produce large amounts of proteases that induce IL-6, IL- 8 and MCP-1 production by airway epithelial cells; these enzymes also disrupt epithelial tight junctions and induce cellular desquamation [26,52-54]. Recently, Porter et al. reported that proteases derived from $A$. niger induce robust allergic lung disease in mice [7].

Most recently, it has been noted that proteases activate protease activated receptors (PARs). PARs are Gprotein coupled receptors present on the airway cells and other cells such as mast cells, eosinophils, neutrophils, macrophages, and lymphocytes [55]. To date, four PARs have been identified; PAR-2 is the most important in allergic airway disease owing to its increased expression on the airways of asthmatic patients [56]. Interestingly, injured airway epithelial cells also secrete trypsin, a PAR-2 agonist that further aggravates allergic inflammatory responses. Using murine models, PAR-2 has been reported to mediate pulmonary eosinophilc infiltration and airway hyperreactivity suggesting a role in exacerbating Th2-mediated responses [57]. Moreover, PAR-2 promotes fibrosis and increased IgE production in allergic diseases (reviewed in [55]). The role of TLRs in regulating PARs signaling and inflammatory responses to A. fumigatus has also been reported. Studies by Moretti et al. reported that A. fumigatus proteases promote host pulmonary inflammatory responses by downregulating PAR-2 expression through a TLR-4 dependent mechanism [58]. Thus, it is possible that proteases secreted by $A$. fumigatus growing on airway epithelium trigger IgG and IgE mediated allergic responses through crosstalk between PARs and TLRsmediated signaling pathways leading to pulmonary complications as ABPA.

Bypassing of the tolerogenic mechanisms is also required to provoke Th2-mediated allergic responses in asthma patients [59]. Studies by Kheradmand et al. showed that fungal proteases have the capability to abort airway tolerance and when instilled in airways can activate Th2-mediated allergic responses without requiring adjuvant priming [49]. DCs also have an important role in maintaining tolerance in lungs by production of IL-10, an immunoregulatory cytokine that induces development of TGF- $\beta$ expressing CD $4+$ T-regulatory cells (Tregs) [60]. In a recent study, Kriendler et al. showed that CD4+ T-cells from cohort of A. fumigatus colonized non-ABPA CF patients had an increased frequency of TGF- $\beta$-expressing Tregs compared to CFABPA patients [48]. This study suggested that tolerance against $A$. fumigatus antigens in CF-ABPA patients is defective and correlated to vitamin-D deficiency.

\section{Fungal Cell Wall components}

The fungal cell wall is primarily composed of polysaccharides such as galactomannan, chitin, $\alpha$ - and $\beta$-glucans [61]. It is now well documented that the cell wall of swollen or germinated A. fumigatus conidia is composed of $\beta$-glucan, which triggers Dectin- 1 mediated inflammatory responses [62-64]. Dectin-1 activated DCs promote the differentiation of Th17 and Th1 cells in vivo and can also convert Tregs into Th17 cells $[65,66]$. The role of Dectin-1 in airway epithelial cells is not well defined; however, recent studies did show Dectin-1 surface expression after TLR-2 stimulation with Mycobacteria and fungal antigens $[67,68]\}$. CF airway epithelial cells were reported to have decreased expression of TLR-4 compared to healthy subjects leading to reduced innate immune responses to $P$. aeruginosa infection [69]. It is likely that the host genetic makeup determines TLR- and C-type lectin receptor(s)-specific immune responses to A. fumigatus cell wall components.

Chitin has been shown to induce host-chitinases in an A. fumigatus-infected guinea pig model which was diminished by an anti-fungal treatment [70]. Mice challenged with chitin demonstrated infiltration of IL-4 expressing eosinophils and basophils in lungs; this did not occur with chitin pretreated with acidic mammalian 
chitinase (AMCase) or in mice overexpressing AMCase [71]. AMCase is known to be expressed by murine airway epithelial cells and alveolar macrophages, and has been reported to impart anti-fungal immunity against chitin-containing organisms [72]. In this regard, Chen et al. recently reported in vitro inhibition of fungal activity by AMCase [73]. Thus, pulmonary immune response to various fungal components could determine the outcome towards protective or pathogenic.

\section{Host Genetic Susceptibility Human leukocyte antigen (HLA) alleles}

Genetic studies have revealed that the expression of specific MHC II alleles could determine development or protection against ABPA [74]. The frequency of HLADR2 (DRB1 *1501 and DRB1 *1503) or DR5 alleles has been reported to be higher in ABPA patients compared to CF or in asthmatic patients without ABPA [74]. This group also suggested the role of HLA-DRB1 "1502 as a resistance allele against the development of ABPA. Using humanized transgenic mice, they reported that $A$. fumigatus infection in DRB1*1501 and DRB1 *1503 strains cause profound ABPA-like pathology while the HLA-DRB1 "1502 strain mounts a protective Th1-type response [75]. It is now becoming clear that $\mathrm{T}$ cell receptor-MHC peptide ligand interactions play an important role in regulating the activation of immune responses and Th1/Th2 cytokine balance [76].

\section{Surfactant protein-A (SP-A) gene and mannan-binding lectin (MBL) polymorphisms}

Genetic association studies have shown that polymorphisms in the SP-A and MBL gene lead to a predisposition to develop ABPA [77-79]. Saxena et al. showed that ABPA patients have a higher frequency of the A1660G SP-A2 allele than matched controls [77]. In line with this, another study also reported that ABPA patients have increased frequency of the $\mathrm{T}$ allele at $\mathrm{T} 1492 \mathrm{C}$ and the $\mathrm{G}$ allele at $\mathrm{G} 1649 \mathrm{C}$ of SP-A2 gene, and also higher frequency of TT genotype (71\%) at 1492 of SP-A2 than controls [79]. Patients with the 1011A MBL allele were observed to have clinical features consistent with ABPA, such as increased eosinophilia, total IgE antibodies and lower FEV1 values [78]. Using murine models of allergic and invasive aspergillosis, the therapeutic potential of SP-A/D and MBL has been reported by Madan and colleagues (reviewed in [80]). These studies suggest a role of surfactant proteins and lectins as possible modulators of A. fumigatus-induced inflammation and allergy.

\section{Cytokine gene polymorphisms}

Patients with ABPA have a higher frequency of the IL$15+13689^{*} \mathrm{~A}$ allele and A/A genotype with a lower frequency of the TNF-alpha-308*A/A genotype [81].
Another study reported that ABPA patients have a single nucleotide polymorphism (SNP) in the extracellular IL-4 receptor alpha, ile75val, which could lead to increased sensitivity to IL-4 stimulation [82]. Increased risk of A. fumigatus colonization in CF patients has been associated with polymorphisms in the promoter region of the IL-10 gene; there is a significant correlation between the $-1082 \mathrm{GG}$ genotype with $A$. fumigatus colonization and ABPA [83].

\section{Polymorphisms in Chitinase and Chitinase-like proteins}

Chitinases are enzymes known to cleave chitin present in fungal walls, parasites, insects and crustaceans [84]. Polymorphisms in two mammalian chitinases viz. AMCase and chitotrisidase (CHIT), and chitinase-like proteins such as YKL- 40 have been reported to play important role in asthma susceptibility [84]. Polymorphisms in the AMCase gene are known to be associated with asthma $[85,86]$. Mutations in CHIT1 gene were also reported in patients with SAFS and can also be a risk factor for ABPA [87]. It has also been shown that high mold exposure can significantly modulate the effect of SNPs in CHIT1 gene on severe asthma exacerbations leading to increased hospitalizations- an example of gene-environment interactions as a determinant for an outcome of the disease [88].

\section{Conclusions}

Taken together, it is now becoming evident that respiratory complications caused by A. fumigatus are the result of genes and the environment such that poor airway clearance of fungal spores drives a skewed adaptive response, and subsequent inflammation-driven lung damage. It is intriguing that we all inhale $A$. fumigatus conidia but only some people develop pathological responses to this fungus. Differences in make-up of multiple PRRs and cytokine genes in the propagation of inflammatory responses are involved in overall risks for allergic responses to fungi. More studies are needed to define precise interaction and decode genetic susceptibilities.

List of abbreviations used

ABPA: Allergic bronchopulmonary aspergillosis; CF: Cystic fibrosis; Th: Thelper; DCs: Dendritic cells; PARs: Protease activated receptors; TLRs: Toll like receptors; CFTR: Cystic fibrosis transmembrane conductance regulator; SNP: Single nucleotide polymorphism; AMCase: Acidic mammalian chitinase; SAFS: Severe asthma with fungal sensitization; Tregs: T-regulatory cells; PRRs: Pattern recognition receptors; CHIT: Chitotrisidase.

\section{Acknowledgements}

The authors gratefully acknowledge Dr. Janet Staab, Dr. Edmond Byrnes, Dr. Simon Dufresne, and Dr. Kausik Datta for their useful suggestions for the manuscript.

\section{Author details}

${ }^{1}$ School of Medicine, Johns Hopkins University, Baltimore, MD, USA. ${ }^{2}$ The Sidney Kimmel Cancer Center, Baltimore, MD, USA. 


\section{Authors' contributions}

KM and NC wrote the manuscript. All authors read and approved the final manuscript.

\section{Competing interests}

The authors declare that they have no competing interests.

Received: 7 April 2011 Accepted: 10 June 2011 Published: 10 June 2011

\section{References}

1. Simon-Nobbe B, Denk U, Poll V, Rid R, Breitenbach M: The spectrum of fungal allergy. Int Arch Allergy Immunol 2008, 145:58-86.

2. Denning DW, O'Driscoll BR, Hogaboam CM, Bowyer P, Niven RM: The link between fungi and severe asthma: a summary of the evidence. Eur Respir J 2006, 27:615-626.

3. O'Driscoll BR, Powell G, Chew F, Niven RM, Miles JF, Vyas A, Denning DW: Comparison of skin prick tests with specific serum immunoglobulin $E$ in the diagnosis of fungal sensitization in patients with severe asthma. Clin Exp Allergy 2009, 39:1677-1683.

4. Agarwal R, Gupta D: Severe asthma and fungi: current evidence. Med Mycol 2011, 49:S150-157.

5. Penders J, Thijs C, Mommers M, Stobberingh EE, Dompeling E, Reijmerink NE, van den Brandt PA, Kerkhof M, Koppelman GH, Postma DS: Host-microbial interactions in childhood atopy: toll-like receptor 4 (TLR4), CD14, and fecal Escherichia coli. J Allergy Clin Immunol 2010, 125:231-236, e231-235.

6. Vercelli D: Gene-environment interactions in asthma and allergy: the end of the beginning? Curr Opin Allergy Clin Immunol 2010, 10:145-148.

7. Porter P, Susarla SC, Polikepahad S, Qian Y, Hampton J, Kiss A, Vaidya S, Sur S, Ongeri V, Yang T, et al: Link between allergic asthma and airway mucosal infection suggested by proteinase-secreting household fungi. Mucosal Immunol 2009, 2:504-517.

8. Park SJ, Mehrad B: Innate immunity to Aspergillus species. Clin Microbiol Rev 2009, 22:535-551.

9. Hinson KF, Moon AJ, Plummer NS: Broncho-pulmonary aspergillosis; a review and a report of eight new cases. Thorax 1952, 7:317-333.

10. Eaton T, Garrett J, Milne D, Frankel A, Wells AU: Allergic bronchopulmonary aspergillosis in the asthma clinic. A prospective evaluation of CT in the diagnostic algorithm. Chest 2000, 118:66-72.

11. Krasnick J, Greenberger PA, Roberts M, Patterson R: Allergic bronchopulmonary aspergillosis: serologic update for 1995. J Clin Lab Immunol 1995, 46:137-142.

12. Agarwal R, Nath A, Aggarwal AN, Gupta D, Chakrabarti A: Aspergillus hypersensitivity and allergic bronchopulmonary aspergillosis in patients with acute severe asthma in a respiratory intensive care unit in North India. Mycoses 2010, 53:138-143.

13. Fairs A, Agbetile J, Hargadon B, Bourne M, Monteiro WR, Brightling CE, Bradding P, Green RH, Mutalithas K, Desai D, et al: IgE sensitization to Aspergillus fumigatus is associated with reduced lung function in asthma. Am J Respir Crit Care Med 2010, 182:1362-1368.

14. Menzies D, Holmes L, McCumesky G, Prys-Picard C, Niven R: Aspergillus sensitization is associated with airflow limitation and bronchiectasis in severe asthma. Allergy 2011, 66:679-685.

15. Knutsen AP, Bellone C, Kauffman H: Immunopathogenesis of allergic bronchopulmonary aspergillosis in cystic fibrosis. J Cyst Fibros 2002, 1:76-89.

16. Agarwal R: Allergic bronchopulmonary aspergillosis. Chest 2009, 135:805-826.

17. Stevens DA, Moss RB, Kurup VP, Knutsen AP, Greenberger P, Judson MA, Denning DW, Crameri R, Brody AS, Light M, et al: Allergic bronchopulmonary aspergillosis in cystic fibrosis-state of the art: Cystic Fibrosis Foundation Consensus Conference. Clin Infect Dis 2003, 37(Suppl 3):S225-264

18. Ganassini A, Cazzadori A: Invasive pulmonary aspergillosis complicating allergic bronchopulmonary aspergillosis. Respir Med 1995, 89:143-145.

19. Bahous J, Malo JL, Paquin R, Cartier A, Vyas P, Longbottom JL: Allergic bronchopulmonary aspergillosis and sensitization to Aspergillus fumigatus in chronic bronchiectasis in adults. Clin Allergy 1985, 15:571-579.

20. Agarwal R, Srinivas R, Jindal SK: Allergic bronchopulmonary aspergillosis complicating chronic obstructive pulmonary disease. Mycoses 2008, 51:83-85.
21. Eppinger TM, Greenberger PA, White DA, Brown AE, CunninghamRundles C: Sensitization to Aspergillus species in the congenital neutrophil disorders chronic granulomatous disease and hyper-lgE syndrome. J Allergy Clin Immunol 1999, 104:1265-1272.

22. Rosenberg M, Patterson R, Mintzer R, Cooper BJ, Roberts M, Harris KE: Clinical and immunologic criteria for the diagnosis of allergic bronchopulmonary aspergillosis. Ann Intern Med 1977, 86:405-414.

23. Chignard M, Balloy V, Sallenave JM, Si-Tahar M: Role of Toll-like receptors in lung innate defense against invasive aspergillosis. Distinct impact in immunocompetent and immunocompromized hosts. Clin Immunol 2007, 124:238-243.

24. Aimanianda V, Bayry J, Bozza S, Kniemeyer O, Perruccio K, Elluru SR, Clavaud C, Paris S, Brakhage AA, Kaveri SV, et al: Surface hydrophobin prevents immune recognition of airborne fungal spores. Nature 2009, 460:1117-1121.

25. Amitani R, Taylor G, Elezis EN, Llewellyn-Jones C, Mitchell J, Kuze F, Cole PJ, Wilson R: Purification and characterization of factors produced by Aspergillus fumigatus which affect human ciliated respiratory epithelium. Infect Immun 1995, 63:3266-3271.

26. Kauffman HF: Interaction of environmental allergens with airway epithelium as a key component of asthma. Curr Allergy Asthma Rep 2003, 3:101-108.

27. Pihet M, Carrere J, Cimon B, Chabasse D, Delhaes L, Symoens F, Bouchara JP: Occurrence and relevance of filamentous fungi in respiratory secretions of patients with cystic fibrosis-a review. Med Mycol 2009, 47:387-397.

28. Muller FM, Seidler M: Characteristics of pathogenic fungi and antifungal therapy in cystic fibrosis. Expert Rev Anti Infect Ther 2010, 8:957-964.

29. Thomas B, Rutman A, Hirst RA, Haldar P, Wardlaw AJ, Bankart J, Brightling CE, O'Callaghan C: Ciliary dysfunction and ultrastructural abnormalities are features of severe asthma. J Allergy Clin Immunol 2010, 126:722-729, e722.

30. Buchanan PJ, Ernst RK, Elborn JS, Schock B: Role of CFTR, Pseudomonas aeruginosa and Toll-like receptors in cystic fibrosis lung inflammation. Biochem Soc Trans 2009, 37:863-867.

31. Warner JO, Taylor BW, Norman AP, Soothill JF: Association of cystic fibrosis with allergy. Arch Dis Child 1976, 51:507-511.

32. Sudfeld CR, Dasenbrook EC, Merz WG, Carroll KC, Boyle MP: Prevalence and risk factors for recovery of filamentous fungi in individuals with cystic fibrosis. J Cyst Fibros 2010, 9:110-116.

33. Horre R, Symoens F, Delhaes L, Bouchara JP: Fungal respiratory infections in cystic fibrosis: a growing problem. Med Mycol 2010, 48(Suppl 1):S1-3.

34. Nagano Y, Elborn JS, Millar BC, Walker JM, Goldsmith CE, Rendall J, Moore JE: Comparison of techniques to examine the diversity of fungi in adult patients with cystic fibrosis. Med Mycol 2010, 48:166-176, e161.

35. Chotirmall SH, Branagan P, Gunaratnam C, McElvaney NG: Aspergillus/ allergic bronchopulmonary aspergillosis in an Irish cystic fibrosis population: a diagnostically challenging entity. Respir Care 2008, 53:1035-1041

36. Kraemer R, Delosea N, Ballinari P, Gallati S, Crameri R: Effect of allergic bronchopulmonary aspergillosis on lung function in children with cystic fibrosis. Am J Respir Crit Care Med 2006, 174:1211-1220.

37. Wojnarowski C, Eichler I, Gartner C, Gotz M, Renner S, Koller DY, Frischer T: Sensitization to Aspergillus fumigatus and lung function in children with cystic fibrosis. Am J Respir Crit Care Med 1997, 155:1902-1907.

38. Miller PW, Hamosh A, Macek M Jr, Greenberger PA, MacLean J, Walden SM, Slavin RG, Cutting GR: Cystic fibrosis transmembrane conductance regulator (CFTR) gene mutations in allergic bronchopulmonary aspergillosis. Am J Hum Genet 1996, 59:45-51.

39. Chaudhary N, Staab J, Marr KA: In Vitro Studies On The Role Of Cystic Fibrosis Transmembrane Conductance Regulator (CFTR) In Pulmonary Epithelial Cell Interactions To A. fumigatus (Abstract). Journal of Allergy and Clinical Immunology 2010, 125:AB118.

40. Stevens DA, Schwartz HJ, Lee JY, Moskovitz BL, Jerome DC, Catanzaro A Bamberger DM, Weinmann AJ, Tuazon CU, Judson MA, et al: A randomized trial of itraconazole in allergic bronchopulmonary aspergillosis. N Engl J Med 2000, 342:756-762.

41. Wark PA, Gibson PG, Wilson AJ: Azoles for allergic bronchopulmonary aspergillosis associated with asthma. Cochrane Database Syst Rev 2004, CD001108. 
42. Kanthan SK, Bush A, Kemp M, Buchdahl R: Factors effecting impact of Aspergillus fumigatus sensitization in cystic fibrosis. Pediatr Pulmonol 2007, 42:785-793.

43. Moss RB, Hsu YP, Olds L: Cytokine dysregulation in activated cystic fibrosis (CF) peripheral lymphocytes. Clin Exp Immunol 2000, 120:518-525.

44. Stecenko AA, King G, Torii K, Breyer RM, Dworski R, Blackwell TS, Christman JW, Brigham KL: Dysregulated cytokine production in human cystic fibrosis bronchial epithelial cells. Inflammation 2001, 25:145-155.

45. Allard JB, Poynter ME, Marr KA, Cohn L, Rincon M, Whittaker LA: Aspergillus fumigatus generates an enhanced Th2-biased immune response in mice with defective cystic fibrosis transmembrane conductance regulator. J Immunol 2006, 177:5186-5194.

46. Mueller C, Torrez D, Braag S, Martino A, Clarke T, Campbell-Thompson M, Flotte TR: Partial correction of the CFTR-dependent ABPA mouse model with recombinant adeno-associated virus gene transfer of truncated CFTR gene. J Gene Med 2008, 10:51-60.

47. Mueller C, Braag SA, Keeler A, Hodges C, Drumm M, Flotte TR: Lack of Cftr in CD3+ Lymphocytes Leads to Aberrant Cytokine Secretion and Hyperinflammatory Adaptive Immune Responses. Am J Respir Cell Mol Biol 2010.

48. Kreindler JL, Steele C, Nguyen N, Chan YR, Pilewski JM, Alcorn JF, Vyas YM, Aujla SJ, Finelli P, Blanchard M, et al: Vitamin D3 attenuates Th2 responses to Aspergillus fumigatus mounted by CD4+ T cells from cystic fibrosis patients with allergic bronchopulmonary aspergillosis. J Clin Invest 2010, 120:3242-3254

49. Kheradmand F, Kiss A, Xu J, Lee SH, Kolattukudy PE, Corry DB: A proteaseactivated pathway underlying Th cell type 2 activation and allergic lung disease. J Immunol 2002, 169:5904-5911.

50. Lamhamedi-Cherradi SE, Martin RE, Ito T, Kheradmand F, Corry DB, Liu YJ, Moyle M: Fungal proteases induce Th2 polarization through limited dendritic cell maturation and reduced production of IL-12. J Immunol 2008, 180:6000-6009.

51. Kiss A, Montes M, Susarla S, Jaensson EA, Drouin SM, Wetsel RA, Yao Z, Martin R, Hamzeh N, Adelagun $R$, et al: A new mechanism regulating the initiation of allergic airway inflammation. J Allergy Clin Immunol 2007, 120:334-342.

52. Kauffman HF, Tomee JF, van de Riet MA, Timmerman AJ, Borger P: Protease-dependent activation of epithelial cells by fungal allergens leads to morphologic changes and cytokine production. J Allergy Clin Immunol 2000, 105:1185-1193.

53. Yu CJ, Chiou SH, Lai WY, Chiang BL, Chow LP: Characterization of a novel allergen, a major IgE-binding protein from Aspergillus flavus, as an alkaline serine protease. Biochem Biophys Res Commun 1999, 261:669-675.

54. Tomee JF, Wierenga AT, Hiemstra PS, Kauffman HK: Proteases from Aspergillus fumigatus induce release of proinflammatory cytokines and cell detachment in airway epithelial cell lines. J Infect Dis 1997. 176:300-303.

55. Reed $\mathrm{CE}$, Kita $\mathrm{H}$ : The role of protease activation of inflammation in allergic respiratory diseases. J Allergy Clin Immunol 2004, 114:997-1008, quiz 1009

56. Knight DA, Lim S, Scaffidi AK, Roche N, Chung KF, Stewart GA, Thompson PJ: Protease-activated receptors in human airways: upregulation of PAR-2 in respiratory epithelium from patients with asthma. J Allergy Clin Immunol 2001, 108:797-803.

57. Schmidlin F, Amadesi S, Dabbagh K, Lewis DE, Knott P, Bunnett NW Gater PR, Geppetti P, Bertrand C, Stevens ME: Protease-activated receptor 2 mediates eosinophil infiltration and hyperreactivity in allergic inflammation of the airway. J Immunol 2002, 169:5315-5321.

58. Moretti S, Bellocchio S, Bonifazi P, Bozza S, Zelante T, Bistoni F, Romani L: The contribution of PARs to inflammation and immunity to fungi. Mucosal Immunol 2008, 1:156-168.

59. Ray A, Khare A, Krishnamoorthy N, Qi Z, Ray P: Regulatory T cells in many flavors control asthma. Mucosal Immunol 2010, 3:216-229.

60. Ostroukhova M, Seguin-Devaux C, Oriss TB, Dixon-McCarthy B, Yang L, Ameredes BT, Corcoran TE, Ray A: Tolerance induced by inhaled antigen involves CD4(+) T cells expressing membrane-bound TGF-beta and FOXP3. J Clin Invest 2004, 114:28-38.

61. Bernard $M$, Latge JP: Aspergillus fumigatus cell wall: composition and biosynthesis. Med Mycol 2001, 39(Suppl 1):9-17.

62. Bretz C, Gersuk G, Knoblaugh S, Chaudhary N, Randolph-Habecker J, Hackman RC, Staab J, Marr KA: MyD88 signaling contributes to early pulmonary responses to Aspergillus fumigatus. Infect Immun 2008, 76:952-958.

63. Gersuk GM, Underhill DM, Zhu L, Marr KA: Dectin-1 and TLRs permit macrophages to distinguish between different Aspergillus fumigatus cellular states. J Immunol 2006, 176:3717-3724.

64. Hohl TM, Van Epps HL, Rivera A, Morgan LA, Chen PL, Feldmesser M, Pamer EG: Aspergillus fumigatus triggers inflammatory responses by stage-specific beta-glucan display. PLOS Pathog 2005, 1:e30.

65. LeibundGut-Landmann S, Gross O, Robinson MJ, Osorio F, Slack EC, Tsoni SV, Schweighoffer E, Tybulewicz V, Brown GD, Ruland J, Reise Sousa C: Syk- and CARD9-dependent coupling of innate immunity to the induction of T helper cells that produce interleukin 17. Nat Immunol 2007, 8:630-638.

66. Osorio F, LeibundGut-Landmann S, Lochner M, Lahl K, Sparwasser T, Eberl G, Reise Sousa C: DC activated via dectin-1 convert Treg into IL-17 producers. Eur J Immunol 2008, 38:3274-3281.

67. Lee HM, Yuk JM, Shin DM, Jo EK: Dectin-1 is inducible and plays an essential role for mycobacteria-induced innate immune responses in airway epithelial cells. J Clin Immunol 2009, 29:795-805.

68. Cunha C, Di lanni M, Bozza S, Giovannini G, Zagarella S, Zelante T, D'Angelo C, Pierini A, Pitzurra L, Falzetti F, et al: Dectin-1 Y238X polymorphism associates with susceptibility to invasive aspergillosis in hematopoietic transplantation through impairment of both recipientand donor-dependent mechanisms of antifungal immunity. Blood 2010, 116:5394-5402.

69. John G, Yildirim AO, Rubin BK, Gruenert DC, Henke MO: TLR-4-mediated innate immunity is reduced in cystic fibrosis airway cells. Am J Respir Cell Mol Biol 2010, 42:424-431.

70. Overdijk B, Van Steijn GJ, Odds FC: Chitinase levels in guinea pig blood are increased after systemic infection with Aspergillus fumigatus. Glycobiology 1996, 6:627-634.

71. Reese TA, Liang HE, Tager AM, Luster AD, Van Rooijen N, Voehringer $D$, Locksley RM: Chitin induces accumulation in tissue of innate immune cells associated with allergy. Nature 2007, 447:92-96.

72. Zhu Z, Zheng T, Homer RJ, Kim YK, Chen NY, Cohn L, Hamid Q, Elias JA: Acidic mammalian chitinase in asthmatic Th2 inflammation and IL-13 pathway activation. Science 2004, 304:1678-1682.

73. Chen L, Shen Z, Wu J: Expression, purification and in vitro antifungal activity of acidic mammalian chitinase against Candida albicans, Aspergillus fumigatus and Trichophyton rubrum strains. Clin Exp Dermatol 2009, 34:55-60.

74. Chauhan B, Santiago L, Hutcheson PS, Schwartz HJ, Spitznagel E, Castro M, Slavin RG, Bellone CJ: Evidence for the involvement of two different MHC class II regions in susceptibility or protection in allergic bronchopulmonary aspergillosis. J Allergy Clin Immunol 2000, 106:723-729.

75. Koehm S, Slavin RG, Hutcheson PS, Trejo T, David CS, Bellone CJ: HLA-DRB1 alleles control allergic bronchopulmonary aspergillosis-like pulmonary responses in humanized transgenic mice. J Allergy Clin Immunol 2007, 120:570-577.

76. Rogers PR, Croft M: Peptide dose, affinity, and time of differentiation can contribute to the Th1/Th2 cytokine balance. J Immunol 1999, 163:1205-1213.

77. Saxena S, Kumar R, Madan T, Gupta V, Muralidhar K, Sarma PU: Association of polymorphisms in pulmonary surfactant protein $A 1$ and $A 2$ genes with high-altitude pulmonary edema. Chest 2005, 128:1611-1619.

78. Kaur S, Gupta VK, Shah A, Thiel S, Sarma PU, Madan T: Elevated levels of mannan-binding lectin [corrected] (MBL) and eosinophilia in patients of bronchial asthma with allergic rhinitis and allergic bronchopulmonary aspergillosis associate with a novel intronic polymorphism in MBL. Clin Exp Immunol 2006, 143:414-419.

79. Vaid M, Kaur S, Sambatakou H, Madan T, Denning DW, Sarma PU: Distinct alleles of mannose-binding lectin (MBL) and surfactant proteins A (SP-A) in patients with chronic cavitary pulmonary aspergillosis and allergic bronchopulmonary aspergillosis. Clin Chem Lab Med 2007, 45:183-186.

80. Madan T: Potential of lung surfactant proteins, SP-A and SP-D, and mannan binding lectin for therapy and genetic predisposition to allergic and invasive aspergillosis. Recent Pat Inflamm Allergy Drug Discov 2007, 1:183-187.

81. Sambatakou H, Pravica V, Hutchinson IV, Denning DW: Cytokine profiling of pulmonary aspergillosis. Int J Immunogenet 2006, 33:297-302. 
82. Knutsen AP, Kariuki B, Consolino JD, Warrier MR: IL-4 alpha chain receptor (IL-4Ralpha) polymorphisms in allergic bronchopulmonary sspergillosis. Clin Mol Allergy 2006, 4:3.

83. Brouard J, Knauer N, Boelle PY, Corvol H, Henrion-Caude A, Flamant C, Bremont F, Delaisi B, Duhamel JF, Marguet C, et al: Influence of interleukin-10 on Aspergillus fumigatus infection in patients with cystic fibrosis. J Infect Dis 2005, 191:1988-1991.

84. Ober C, Chupp GL: The chitinase and chitinase-like proteins: a review of genetic and functional studies in asthma and immune-mediated diseases. Curr Opin Allergy Clin Immunol 2009, 9:401-408.

85. Bierbaum S, Nickel R, Koch A, Lau S, Deichmann KA, Wahn U, SupertiFurga A, Heinzmann A: Polymorphisms and haplotypes of acid mammalian chitinase are associated with bronchial asthma. Am J Respir Crit Care Med 2005, 172:1505-1509.

86. Chatterjee R, Batra J, Das S, Sharma SK, Ghosh B: Genetic association of acidic mammalian chitinase with atopic asthma and serum total lgE levels. J Allergy Clin Immunol 2008, 122:202-208, 208 e201-207.

87. Vicencio AG, Chupp GL, Tsirilakis K, He X, Kessel A, Nandalike K, Veler $H$, Kipperman S, Young MC, Goldman DL: CHIT1 mutations: genetic risk factor for severe asthma with fungal sensitization? Pediatrics 2010, 126 : e982-985.

88. Wu AC, Lasky-Su J, Rogers CA, Klanderman BJ, Litonjua AA: Fungal exposure modulates the effect of polymorphisms of chitinases on emergency department visits and hospitalizations. Am J Respir Crit Care Med 2010, 182:884-889.

doi:10.1186/2045-7022-1-4

Cite this article as: Chaudhary and Marr: Impact of Aspergillus fumigatus in allergic airway diseases. Clinical and Translational Allergy 2011 1:4.

\section{Submit your next manuscript to BioMed Central and take full advantage of:}

- Convenient online submission

- Thorough peer review

- No space constraints or color figure charges

- Immediate publication on acceptance

- Inclusion in PubMed, CAS, Scopus and Google Scholar

- Research which is freely available for redistribution

Submit your manuscript at www.biomedcentral.com/submit 